\title{
Comparative characteristics of professional predispositions of medical personnel
}

\author{
Renata Markiewicz ${ }^{1} \mathrm{~A}, \mathrm{~B}, \mathrm{C}, \mathrm{D}, \mathrm{E}, \mathrm{F}, \mathrm{G}$, Jacek Gajewski ${ }^{2}{ }_{\mathrm{B}, \mathrm{E}, \mathrm{F}, \text { Diana }}$ Żmuda ${ }^{3} \mathrm{E}, \mathrm{F}$
}

\author{
${ }^{1}$ Department of Psychiatric, Medical University of Lublin \\ ${ }^{2}$ Department of Psychiatry, Psychotherapy and Early Intervention, Medical University of Lublin \\ 3Department of Psychiatric Rehabilitation, Medical University of Lublin
}

\begin{abstract}
Professional predispositions are an important component characterising people working as health care professionals. The aim of this study was to compare professional predispositions of students at medical courses with professionally active nurses. The study methods included a survey (SOPZ) and the Delta questionnaire. The analysis showed there were no differences in levels of sense of threat, responsibility and creativity in all analysed group, as well as while there was a differentiating influence of the sense of control in the analysed group of students.
\end{abstract}

Keywords: job predispositions, nursing staff

\section{Introduction}

It has long been known that performing duties related with medical jobs requires identified predispositions. It includes not only physical condition understood as strength and possibility for optimal working but also - maybe first of all mental condition (resistance to stress, skill of reacting in difficult situations, rational acting) [1]. Mental conditions are basic in the difficult work with human being needing help. Stress, burden with other people's problems, responsibility for their health and life, require resistance during performing standard duties and tasks [2]. We often wonder if each student choosing a medical job has identified predispositions, if each is able to manage with mental burden, to express empathy, authenticity and desire to help other people. Some manual skills can be learned and improved but personality predispositions cannot be acquired. The question appears - what should be such predispositions like, how to categorize them, what should be taken into account during qualifying young people - future staff of health service $[3,4,5]$.

Several works $[9,10,11,12]$ examine this subject, several authors try to answer these questions. Unambiguous interpretation maybe does not exist, but some array and systematization exist. The aim of this paper was a comparative characteristic of professional predispositions in two groups: midwifery and nursing students versus professionally active nurses.

\section{Material and method}

The study was performed in 106 people studying nursing (group 1), 66 people studying midwifery (group 3) and 100 working nurses (group 2). Groups 1 and 2 consisted of students of the Medical University in Lublin, and the control group consisted of nurses employed at Clinical Hospitals in Lublin clinical departments. The aim of the study was to compare professional predisposition of future health care workers with those professionally active with a long-term experience. Any differences found in analysed predisposition would form a basis for a detailed analysis whether people declaring an intent to become a nurse in the future actually meet specific requirements characterising this profession.

The analysed groups were informed about the aim of the study, anonymity, there were adults and able to provide informed consent. The research was performed in 2015, after the pilot study.

We used the questionnaire based on the subject literature [13], preliminary developed by R.Markiewicz and J.Turajczyk, later verified and modified after performed analyses. In the questionnaire, the authors took into account such job predispositions which have been recognized as both important and specific for the medium-level medical staff [13]. Categorisation and question modifications were made for the purposes of the work. The SOPZ included sociodemographic data, data regarding choice of medical job, family tradition and questions allowing to assess: sense of danger (I), family situation (II), introversion and extraversion (III), occupational effectiveness (IV), creativity (V), responsibility (VI), flexibility of behaviour (VII). Categorisation assumed the analysis of chosen variables that determined occupational predispositions of medical staff group. We analysed these variables that were qualified for further statistical tests based on the pilot study. Performed analyses allowed to extract seven-factor scale as one that internal compatibility factor alfa-Cronbach for the scales was at least 0.7 . The assessment of accuracy was done based on comprehensive analysis of content of questions included into the questionnaire. The second used research measure was the Delta Questionnaire (LOC scale) [14]. 
The analysis was based on qualitative data, intergroup comparisons with the LSD test, and correlation analyses aiming at demonstrating a correlation between studied variables, their direction and relationship strength $(\mathrm{p}<0.05)$. All analyses allowed determining comparative characteristics of individual groups using the STATISTICA 9.1 package.

\section{Results}

The analysis of qualitative data indicates that subjects of this study are mainly women from two-parent families (tab. 1).

Table 1 . The analysis of sociodemographic variables

\begin{tabular}{|c|c|c|c|c|c|}
\hline \multicolumn{3}{|c|}{ Analysed variable } & $\begin{array}{c}\text { NS } \\
\text { gr } 1\end{array}$ & $\begin{array}{c}\text { PA } \\
\text { gr } 2\end{array}$ & $\begin{array}{l}\text { MS } \\
\text { gr } 3\end{array}$ \\
\hline \multirow{3}{*}{ Gender } & \multirow[t]{2}{*}{ Women } & $\mathrm{N}$ & 101 & 97 & 66 \\
\hline & & $\%$ & 95.28 & 97.00 & 100.00 \\
\hline & Men & $\begin{array}{l}\mathrm{N} \\
\%\end{array}$ & $\begin{array}{c}5 \\
4.72\end{array}$ & $\begin{array}{c}3 \\
3.00\end{array}$ & $\begin{array}{c}0 \\
0.00\end{array}$ \\
\hline \multirow{5}{*}{$\begin{array}{l}\text { Place of } \\
\text { residence* }\end{array}$} & \multirow{2}{*}{ Town/city } & $\mathrm{N}$ & 51 & 57 & 36 \\
\hline & & $\%$ & 51.00 & 57.58 & 55.38 \\
\hline & \multirow{2}{*}{ County } & $\mathrm{N}$ & 3 & 9 & 0 \\
\hline & & $\%$ & 3.00 & 9.09 & 0.00 \\
\hline & Community & $\begin{array}{l}\mathrm{N} \\
\%\end{array}$ & $\begin{array}{c}46 \\
46.00\end{array}$ & $\begin{array}{c}33 \\
33.33\end{array}$ & $\begin{array}{c}29 \\
44.62\end{array}$ \\
\hline \multirow{5}{*}{ Family } & \multirow{2}{*}{ Two-parent } & $\mathrm{N}$ & 96 & 87 & 60 \\
\hline & & $\%$ & 90.57 & 87.00 & 90.91 \\
\hline & \multirow{2}{*}{ Single-parent } & $\mathrm{N}$ & 7 & 10 & 5 \\
\hline & & $\%$ & 6.60 & 10.00 & 7.58 \\
\hline & Reconstructed & $\begin{array}{l}\mathrm{N} \\
\%\end{array}$ & $\begin{array}{c}3 \\
2.83\end{array}$ & $\begin{array}{c}3 \\
3.00\end{array}$ & $\begin{array}{c}1 \\
1.52\end{array}$ \\
\hline \multirow{8}{*}{$\begin{array}{l}\text { Choice } \\
\text { of job** }\end{array}$} & \multirow{2}{*}{ Random } & $\mathrm{N}$ & 31 & 27 & 14 \\
\hline & & $\%$ & 29.25 & 27.00 & 22.22 \\
\hline & \multirow{2}{*}{ Conscious } & $\mathrm{N}$ & 54 & 49 & 38 \\
\hline & & $\%$ & 50.94 & 49.00 & 60.32 \\
\hline & \multirow{2}{*}{ Family suggestion } & $\mathrm{N}$ & 14 & 15 & 11 \\
\hline & & $\%$ & 13.21 & 15.00 & 17.46 \\
\hline & \multirow{2}{*}{$\begin{array}{l}\text { Friends } \\
\text { suggestion }\end{array}$} & $\mathrm{N}$ & 7 & 9 & 0 \\
\hline & & $\%$ & $6.60 \%$ & 9.00 & 0.00 \\
\hline \multirow{6}{*}{$\begin{array}{l}\text { Is the job in } \\
\text { accordance } \\
\text { with the } \\
\text { interests?* }\end{array}$} & \multirow{2}{*}{ Yes } & $\mathrm{N}$ & 25 & 89 & 8 \\
\hline & & $\%$ & 25.51 & 89.00 & 12.12 \\
\hline & \multirow{2}{*}{ No } & $\mathrm{N}$ & 3 & 8 & 0 \\
\hline & & $\%$ & 3.06 & 8.00 & 0.00 \\
\hline & \multirow{2}{*}{ Not applicable } & $\mathrm{N}$ & 70 & 3 & 58 \\
\hline & & $\%$ & 71.43 & 3.00 & 87.88 \\
\hline & & $\mathrm{N}$ & 14 & 2 & 5 \\
\hline perform & Yes & $\%$ & 13.21 & 2.00 & 7.58 \\
\hline medical & & $\mathrm{N}$ & 92 & 98 & 61 \\
\hline & No & $\%$ & 86.79 & 98.00 & 92.42 \\
\hline & & $\mathrm{N}$ & 91 & 94 & 60 \\
\hline & Yes & $\%$ & 85.85 & 94.00 & 90.91 \\
\hline Owing & No & $\mathrm{N}$ & 15 & 5 & 5 \\
\hline siblings & No & $\%$ & 14.15 & 5.00 & 7.58 \\
\hline & & $\mathrm{N}$ & 0 & 1 & 1 \\
\hline & Yes, half-siblings & $\%$ & 0.00 & 1.00 & 1.52 \\
\hline & & $\mathrm{N}$ & 13 & 9 & 5 \\
\hline & Yes & $\%$ & 12.26 & 9.00 & 7.58 \\
\hline Have siblings & & $\mathrm{N}$ & 82 & 85 & 56 \\
\hline medical & No & $\%$ & 77.36 & 85.00 & 84.85 \\
\hline & & $\mathrm{N}$ & 11 & 6 & 5 \\
\hline & Not applicable & $\%$ & 10.38 & 6.00 & 7.58 \\
\hline & & $\mathrm{N}$ & 5 & 6 & 6 \\
\hline Is the family & Yes & $\%$ & 4.72 & 6.00 & 9.09 \\
\hline traalcion of & & $\mathrm{N}$ & 101 & 94 & 60 \\
\hline medical job? & No & $\%$ & 95.28 & 94.00 & 90.91 \\
\hline & & $\mathrm{N}$ & 106 & 100 & 66 \\
\hline & neral & $\%$ & 38.97 & 36.76 & 24.27 \\
\hline
\end{tabular}

* Analysis for 264 individuals, remaining respondents did not answer this question ** Analysis for 269 individuals, remaining respondents did not answer this question NS - gr 1, nursing students, PA - gr 2, professionally active nurses, MS - gr 3, midwifery students
On average, every second questioned person came from a town or a city. The profession was an informed choice in case of $50 \%$ of people studying nursing, $60 \%$ of people studying midwifery, and $49 \%$ of professionally active nurses. The selected profession was not associated with continuing family traditions. Professionally active nurses declared that their current job conformed to their interests (tab. 1).

The average age of examined students, both at nursing and at midwifery courses, was 22 years, and in the group of professionally active nurses it was 43 years.

Table 2. Age of the studied groups

\begin{tabular}{|l|l|c|c|c|c|}
\hline $\begin{array}{c}\text { Age of the } \\
\text { studied groups }\end{array}$ & $\begin{array}{l}\text { N of } \\
\text { important }\end{array}$ & Average & Min. & Max. & SD \\
\hline NS(gr 1) & 106 & 21.82 & 20 & 37 & 2.48 \\
\hline PA (gr 2) & 100 & 43.22 & 30 & 55 & 5.71 \\
\hline MS (gr 3) & 66 & 21.56 & 20 & 27 & 1.83 \\
\hline
\end{tabular}

NS - gr 1, nursing students, PA - gr 2, professionally active nurses, MS - gr 3, midwifery students, SD- Standard deviation

Fifty-one percent of professionally active nurses (gr 2) had a long-term professional experience, ranging from 16 to 25 years. Eighty-six percent of them were employed at hospital operative departments (mainly surgery, internal medicine, anaesthesiology) (table 3).

Table 3. The length of working and ward profile of working nurses (gr 2)

\begin{tabular}{|c|l|c|c|}
\hline \multicolumn{2}{|c|}{ PA (gr 2) } & N & \% \\
\hline \multirow{3}{*}{ Length of } & 1) to 15 years & 24 & 24.00 \\
working & 2) 16-25 years & 51 & 51.00 \\
& 3) 26 years and more & 25 & 25.00 \\
\cline { 2 - 4 } & \multicolumn{2}{|c|}{ M=21.4 SD=6.70 Min=8 Max=37 } \\
\hline \multirow{5}{*}{ Profile } & 1) Z/S (operative, hospital) & 86 & 86.00 \\
& 2) Nz/P (non-operative, & 7 & 7.00 \\
& outpatient clinic) & 7 & 7.00 \\
\hline In general & 3) S (environment) & 100 & 100.00 \\
\hline
\end{tabular}

M - mean, SD - standard deviation, Min - minimal value, Max - maximal value

NS - gr 1, nursing students, PA - gr 2, professionally active nurses, MS - gr 3, midwifery students

Comparisons between groups indicate there are no statistically significant differences between the studied groups in results of intensity in the LOC scale. For comparisons based on SOPZ scale, such differences were found for introversion and extraversion, effectiveness and behavioural flexibility.

In comparisons between groups concerning introversion and extraversions, differences were found between NS (gr 1) and PA (gr 2), and between PA (gr 2) and MS (gr 3) $((F=15.941 ; p<0.001))$. This implies a tendency for intensified introvert behaviours in the PA group (gr 2). The above analysis concerned establishing, maintaining and satisfaction associated with relations with other people. The studies show that professionally active nurses have limited interpersonal contacts, are less satisfied with such contacts, and have a limited number of acquaintances. 
In comparisons between groups concerning professional effectiveness, differences were found between all groups $(\mathrm{F}=26.473 ; \mathrm{p}<0.001)$. The analysis concerned: physical fitness, duration of fatigue after performing a specific task, as well as quality and time required for its performance. The lowest results were noted in group NS (gr 1), with statistically higher results in group MS (gr 3) and the highest amongst PA nurses (gr 2).

In comparisons between groups concerning behavioural flexibility, differences were noted between PA nurses (gr 2) and MS (gr 3) (F=3.849; p<0.022). PA nurses (gr 2) showed more flexible behaviour than subjects from the MS group (gr 3). No significant differences were observed between PA nurses (gr 2) and NS (gr 1). The analysis focused on: acceptance of management supervision, rights of managers, and subjecting to professional responsibilities.

No significant differences were noted between studied groups for sense of threat, family situation, creativity and responsibility.

The correlation analysis shows that in the studied groups there is a statistically significant positive correlation between the LOC result and the "sense of threat" $(r=0.300 ; p<0.001)$. This indicates that the survey participants are, in general, more sad, more depressed and tired, with additionally increased sense of external control.

The correlation analysis also shows a statistically significant negative correlation between the LOC result and "introversion and extraversion" $(\mathrm{r}=-0.223$; $\mathrm{p}<0.001)$. This indicates that the subjects have limited and less satisfying contacts with other people.
Furthermore, the correlation analysis showed a statistically significant negative correlation between the LOC result and "creativity" ( $\mathrm{r}=-0.133 ; \mathrm{p}<0.029)$. This indicates that a sense of increased external control results in reduced creativity and innovativeness in the studied subjects.

The correlation analysis also implies a statistically significant negative correlation between the LOC result and "responsibility". This indicates that a sense of increased external control results in reduced responsibility. The discussed results are shown in Table 5.

Additionally, the correlation analysis in group NS (gr 1) showed a statistically significant negative correlation between the LOC result and "family situation" ( $r=-0.207$; $\mathrm{p}<0.033$ ), implying that increased external control has a negative impact on relations in a family. In group MS (gr 3 ), a negative correlation was also noted between the LOC result and "professional effectiveness" ( $\mathrm{r}=-0.414$; $\mathrm{p}<0.001$ ), implying that an increase in the sense of external control results in a decreased work effectiveness and low performance quality.

\section{Discussion}

Based on the results we can state that all studied groups have similar level of sense of danger, creativity and responsibility for performing occupational tasks. We can assume that there are positive indicators because both sense of danger indicating similar feeling of various emotional states (sadness, depression, joy, anger) and creativity indicating ability for cooperation and using innovative solutions are undoubtedly features that should be present in medical staff.

Table 4. Inter-group comparisons based on LOC and SOPZ scales

\begin{tabular}{|l|c|c|c|c|c|c|}
\hline $\begin{array}{c}\text { Analysed variable } \\
\text { SOPZ }\end{array}$ & $\begin{array}{c}\text { NS (gr 1) } \\
\text { [average] }\end{array}$ & $\begin{array}{c}\text { PA (gr 2) } \\
\text { [average] }\end{array}$ & $\begin{array}{c}\text { MS (gr 3) } \\
\text { [average] }\end{array}$ & F & P & $\begin{array}{c}\text { Inter-group com- } \\
\text { parisons (NIR test) }\end{array}$ \\
\hline I. Sense of threat & 1.61 & 1.58 & 1.55 & 0.240 & 0.787 & - \\
\hline II. Family situation & 3.01 & 2.89 & 3.03 & 1.186 & 0.307 & - \\
\hline III. Introversion and extraversion & $\mathbf{2 . 1 9}$ & 1.73 & $\mathbf{2 . 1 4}$ & 15.941 & $<0.001$ & I-II, II-III \\
\hline IV. Effectivity & $\mathbf{2 . 5 8}$ & $\mathbf{3 . 1 9}$ & $\mathbf{2 . 8 3}$ & 26.473 & $<0.001$ & I-II, I-III, II-III \\
\hline V. Creativity & 2.65 & 2.76 & 2.76 & 1.401 & 0.248 & - \\
\hline VI. Responsibility & 2.79 & 2.76 & 2.67 & 1.576 & 0.209 & - \\
\hline VII. Flexibility & 1.11 & $\mathbf{1 . 2 2}$ & $\mathbf{1 . 0 1}$ & 3.849 & 0.022 & II-III \\
\hline LOC & 4.58 & 5.39 & 4.86 & 2.438 & 0.089 & - \\
\hline
\end{tabular}

NS - gr 1, nursing students, PA - gr 2, professionally active nurses, MS - gr 3, midwifery students

Table 5. Results of correlations based on the Delta Questionnaire and SOPZ

\begin{tabular}{|l|c|c|c|c|c|c|c|c|}
\hline \multirow{2}{*}{\multicolumn{1}{|c}{ Subscales of SOPZ }} & \multicolumn{9}{c|}{ Correlations with LOC } \\
\cline { 2 - 9 } & \multicolumn{2}{|c|}{ Whole group } & \multicolumn{2}{c|}{ NS (gr 1) } & \multicolumn{2}{c|}{ PA (gr 2) } & \multicolumn{2}{c|}{ MS (gr 3) } \\
\cline { 2 - 9 } & $\mathrm{R}$ & $\mathrm{P}$ & $\mathrm{r}$ & $\mathrm{P}$ & $\mathrm{R}$ & $\mathrm{P}$ & $\mathrm{R}$ & $\mathrm{P}$ \\
\hline I Sense of threat & 0.300 & $<0.001$ & 0.449 & $<0.001$ & 0.128 & 0.204 & 0.319 & 0.009 \\
\hline II Family situation & -0.138 & 0.023 & -0.207 & 0.033 & -0.044 & 0.662 & -0.128 & 0.305 \\
\hline III Introversion and extraversion & -0.223 & $<0.001$ & -0.293 & 0.002 & -0.165 & 0.101 & -0.104 & 0.404 \\
\hline IV Occupational effectivity & -0.049 & 0.426 & -0.112 & 0.255 & 0.136 & 0.178 & -0.414 & 0.001 \\
\hline V Creativity & -0.133 & 0.029 & -0.197 & 0.043 & -0.095 & 0.345 & -0.139 & 0.267 \\
\hline VI Responsibility & -0.120 & 0.048 & -0.007 & 0.946 & -0.168 & 0.095 & -0.183 & 0.141 \\
\hline VII Flexibility of behaviour & 0.058 & 0.343 & 0.130 & 0.185 & 0.013 & 0.899 & -0.053 & 0.670 \\
\hline
\end{tabular}

NS - gr 1, nursing students, PA - gr 2, professionally active nurses, MS - gr 3, midwifery students 
These indicators evidence abilities related to understanding of another human being, empathy, preference of cooperation. Responsibility in performing occupational tasks seems controversial. From the logical point of view it is clear and does not require discussion; the results of the work confirm it but there are some discrepancies in the literature. Hudek-Knezevic show that scrupulousness and introversion as a role conflict limit occupational effectiveness and over-submission is a negative predictor of burnout [9].

The question appears - where is the reason? We cannot acknowledge that responsibility in medical jobs is an undesirable trait.

Supposedly one can assume that "moral" and "dummy" responsibility exist. Presumably "dummy responsibility" characterizes perfect, emotionally overengaged and anxiety people and "moral responsibility" characterizes people whose behaviour, feelings and thoughts are the result of internal activity. Individuals showing "moral responsibility" have activity style focused on task [15]. In stressful situation they do not experience emotional over-engagement, they concentrate on solving problems, their style goes to solve specific task. People showing style focused on emotions or avoiding style are presumably people with "dummy responsibility" characterized by excess of emotions, anxiety, introvert and avoiding behaviour. Responsibility viewed in this aspect forces specific behaviour in them, has not features of internal activity - only responsibility "if necessary".

If we want responsibility to be positive dimensionwe should be striving for shaping such attitudes in medical staff to make them aware that they "have moral duty for responsibility for their actions", that their actions are caused by internal activity and need, not obligation. Undoubtedly it requires a lot of work both at the educational and occupational level; creating proper conditions to make possible personal development, occupational perfecting, and shaping attitudes according ethical rules [16].

Reacting style and responsibility are related to sense of control which - according to available data - has huge impact on creativity and flexibility of behaviour. External sense of control that is an inherent element of interactions and interpersonal relationships cannot cause dependence on others, loss of rights to making own decisions, expression of thoughts and views. Excessive external dependence often locks personal development, leads to introvert and aggressive behaviour and even according to Litzke, to burnout [17].

Data indicates that group 2 shows introvert behaviour and restrictions in interpersonal relationships, reluctance to maintain them. Probably there are some trends toward burnout development in this group. Appearance of this syndrome means worse quality of care, decrease of work effectivity and dissatisfaction among patients.
Summarizing, efforts should be made that medical staff will not depend on external decisions, will have a right to decide, show creativity, innovation, strive toward personal development and occupational effectiveness. It is clear that there are some situations and requirements of the employer for employee which condition manager control but professional management is completely different from requiring absolute subordination.

\section{Conclusions}

1. The studied groups do not differ in their levels of sense of threat, responsibility and creativity.

2. A sense of external control negatively affects creativity and behavioural flexibility.

3. A sense of external control is characteristic for the studied groups of students, while it is not characteristic for professionally active nurses.

\section{References:}

1. Parkes KR. Coping in stressful episodes: the role of individual differences, environmental factors, and situational characteristics. J Pers Soc Psychol., 1986;51(6):1277-92.

2. Barlem JG, Lunardi VL, Barlem EL, Ramos AM, Figueira AB, Fornari NC. Nursing beliefs and actions in exercising patient advocacy in a hospital context. Rev Esc Enferm USP., 2015;49(5):8118.

3. Burgess L, Irvine F, Wallymahmed A. Personality, stress and coping in intensive care nurses: a descriptive exploratory study. Nurs Crit Care., 2010;15(3):129-40.

4. Baldacchino DR, Galea P. Student nurses' personality traits and the nursing profession: part 2. Br J Nurs., 2012;21(9):530-5.

5. Watson R, Deary I, Thompson D, Li G. A study of stress and burnout in nursing students in Hong Kong: a questionnaire survey. Int J Nurs Stud. 2008; 45(10):1534-42.

6. Jenkins SH, Astroth KS, Woith WM. Non-Critical-Care Nurses' Perceptions of Facilitators and Barriers to Rapid Response Team Activation. J Nurses Prof Dev., 2015;31(5):264-70.

7. Shimizutani M1, Odagiri Y, Ohya Y, Shimomitsu T, Kristensen TS, Maruta T, Iimori M. Relationship of nurse burnout with personality characteristics and coping behaviors. Ind Health, 2008;46(4):326-35.H.

8. Ellershaw J1, Fullarton C, Rodwell J, Mcwilliams J. Conscientiousness, openness to experience and extraversion as predictors of nursing work performance: a facet-level analysis. J Nurs Manag., 2015; 3.

9. Hudek-Knezevic J., Kalebic MaglicaB., Krapić N. Personality, organizational stress, and attitudes toward work as prospective predictors of Professional burnout in hospital nurses. Croat Med J.,2011:15:52(4):538-49.

10. Canadas-De la Fuente, Vargas C., San Luis C., Garcia I. Risk factors and prevalence of burnout syndrome In the nursing profession. Int J Nurs Stud., 2015;52(1):240-9.

11. Bohle P., tilley A.J. Predicting mood change on Wight Shift. Ergonomics,1993:36(1-3):125-33.

12. Tornroos M., Hintsanen M., Hintsa T., Jokela M., Pulkki-Raback L., Hutri-Kahonen N., Keltikangas-Jarvinen L. Associations between five-factor model traits and perceived job strain: a populationbased study. J Occup Health Psychol.,2013;18(4):492-500.

13. Strelau J., Zawadzki B. Kwestionariusz temperament PTS., Warszawa;1998:s.67-75. 
14. Drwal R.Ł. Opracowanie kwestionariusza Delta do pomiaru poczucia kontroli. Studia Psychologiczne, 1979;1:67-83.

15. Parker JDA, Endler NS. Coping with doping assessment: A critical review. European Journal of Personality, 1992; 6(5).

16. Dudek B., Koniarek J., Szymczak W. Stres związany z pracą a teoria zachowania zasobów Stevana Hobfolla. Medycyna Pracy, 2007;58(4):317-325.

17. Litzke S., Schuh H. Stres, lobbing i wypalenie zawodowe, Gdańskie Wydawnictwo Psychologiczne, Gdańsk 2006.

\section{Correspondence address}

Renata Markiewicz

Zakład Pielęgniarstwa Psychiatrycznego Uniwersytetu Medycznego w Lublinie

ul. Szkolna 18, 20-093 Lublin

e-mail: renata_m4@vp.pl

Otrzymano: 07.03.2016

Zrecenzowano: 16.06.2016

Przyjęto do druku: 07.09.2016 